\title{
Update on the management of chronic rhinosinusitis
}

\author{
This article was published in the following Dove Press journal: \\ Infection and Drug Resistance \\ 22 January 2013 \\ Number of times this article has been viewed
}

\section{Rachel B Cain \\ Devyani Lal}

Department of Otorhinolaryngology, Mayo Clinic, Phoenix, AZ, USA

Correspondence: Devyani Lal Department of Otorhinolaryngology, Mayo Clinic, 5777 East Mayo Boulevard, Phoenix, AZ 85054, USA

$\mathrm{Tel}+\mathrm{I} 4803422928$

Fax + I 4803422626

Email lal.devyani@hotmail.com

\begin{abstract}
Chronic rhinosinusitis (CRS) is a common disorder characterized by mucosal inflammation of the nose and paranasal sinuses with sinonasal symptoms persisting for greater than 12 weeks. The etiology of CRS is incompletely understood. Current understanding supports inflammation, rather than infection, as the dominant etiologic factor. CRS significantly impacts patients' quality of life and health care expenditure. There is no standard management of CRS. Treatment strategies differ based on divergent etiologies of the various CRS subclasses. Both systemic and topical agents are used. These interventions differ in CRS with nasal polyposis (CRSwNP), CRS without nasal polyposis (CRSsNP) and specific situations such as allergic fungal rhinosinusitis or aspirin-exacerbated respiratory disease. Antibiotics are the most commonly prescribed medication for CRS, but their role in management is not strongly supported by high-level studies. This paper provides a succinct review of the evidence supporting or refuting common therapeutic agents in the management of CRS. Novel and emerging strategies will also be discussed.
\end{abstract}

Keywords: review, evidence-based, sinusitis

\section{Introduction}

Chronic rhinosinusitis (CRS) is diagnosed when specific sinonasal symptoms lasting 12 or more weeks are confirmed by nasal endoscopy or radiographic imaging (Figure 1). ${ }^{1}$ CRS is best considered as a group of heterogeneous disorders from a multitude of causes that result in mild to severe symptomatic inflammation of the sinonasal mucosa (Figure 2). ${ }^{2}$ The management of this complex and diverse disease is therefore a challenge. Much ongoing research is being directed toward the investigation of treatment strategies, as well as developing criteria for diagnosing the various CRS subsets. The most simplified classification divides CRS into those patients who have nasal polyps (CRSwNP) and those without (CRSsNP) (Figure 3). ${ }^{3}$

Medical therapy of CRS is a key strategy, with surgery playing a vital adjunctive role. Medical therapy is directed toward treatment of the underlying etiology, as well as the resultant inflammation. A variety of systemic and topical therapeutic agents are commonly employed. These include corticosteroids, antimicrobials, and immune modulating medications. As CRS is a chronic disease, there are concerns related to the use of systemic agents over prolonged periods. Long-term use of corticosteroids and antibiotics may lead to adverse effects, drug interactions, and antimicrobial resistance. The development of topical therapy delivered directly to the sinonasal cavity has created an alternative treatment strategy to help potentiate these concerns. Many therapeutic agents submit your manuscript $\mid$ www.dovepress.com

Dovepress

http://dx.doi.org// 0.2147/IDR.S26134
Infection and Drug Resistance 2013:6 I-I4

(C) 2013 Cain and Lal, publisher and licensee Dove Medical Press Ltd. This is an Open Access article which permits unrestricted noncommercial use, provided the original work is properly cited. 


\section{- American Academy of Otolaryngology - Head and Neck Surgery criteria}

- $\geq 12$ week duration of $\geq 2$ of following:

- Mucopurulent drainage

- Nasal obstruction

- Facial pain/pressure/fullness

- Decreased sense of smell

AND

- Inflammation by one or more objective criteria

- Endoscopy: pus, mucosal edema or polyps

- Imaging showing inflammation of the paranasal sinuses

Figure I Diagnosis of CRS.

Note: (C) 2007 Sage Publications. Reproduced with permission from Rosenfeld RM, et al. Clinical practice guideline: adult sinusitis. Otolaryngol Head Neck Surg. 2007; I37(3 Suppl)SI-S3I.

can now be delivered into the sinonasal cavity by a variety of delivery methods, such as irrigations, sprays, and aerosols.

This paper will provide a succinct summary of current and emerging evidence-based strategies to treat CRS.

\section{Epidemiology}

CRS is estimated to result in over 18 million physician visits in the United States each year ${ }^{4}$ and is self-diagnosed in one in seven adults. ${ }^{5}$ It is also the fifth most common diagnosis for an antibiotic prescription. ${ }^{6}$ Despite its prevalence, there is a surprising paucity of accurate epidemiologic data for CRS, especially CRSsNP. Patient surveys in the United States have found a $15 \%-16 \%$ prevalence of CRS $; ;^{7,8}$ however, a prevalence of only 2\% was found using ICD-9 (International Classification of Diseases, Ninth Revision) codes as an identifier. ${ }^{9}$ In studies from Canada, Korea, Scotland, Europe, and Sao Paulo, prevalence of CRS ranges from $1 \%-11 \% .^{10-14}$

Population-based studies of CRSwNP from Sweden, Korea, Finland, and France report the prevalence of CRSwNP to lie between $0.5 \%$ and $4.3 \%{ }^{15-18}$ Autopsy studies reveal a higher prevalence between $2 \%$ and $42 \%$, with more polyps found in dissected naso-ethmoidal blocks and endoscopic sinus surgery (ESS) than with anterior rhinoscopy alone. . $^{19,20}$ Men and women are both affected by CRSwNP, with some discordance in the literature as to which sex is more frequently affected. In general, nasal polyps occur in all races and become more common with age, with the average age of onset being 42 years. ${ }^{18}$

\section{Etiology}

Regarding the etiology of CRS, numerous hypotheses have been proposed with a great deal of overlap, supporting a multifactorial basis. One classification method separates potential contributing entities into host and environmental factors (Figure 2). ${ }^{2}$ Although comprehensive, this scheme fails to illustrate causal relationships and host-environment interactions. The heterogeneous nature of CRS is important to understand when planning treatment for this diverse group of patients whose disease may have arisen from very different underlying etiologies.

In a broad generalization, CRSwNP in the Caucasian population is associated more closely with high tissue eosinophilia and increased T helper (Th)-2 cytokine expression (interleukin [IL]-5 and IL-13) as well as nasal obstruction and smell loss. Meanwhile, CRSsNP may have more Th-1 polarization and less eosinophilic infiltration (Figure 3). ${ }^{3}$ However, these characterizations may not hold true for other ethnic populations. Dysfunction in the eicosanoid pathway, with increased synthesis of pro-inflammatory leukotrienes and decreased synthesis of anti-inflammatory prostaglandins, has been proposed as a mechanism for both aspirin-sensitive and aspirin-tolerant CRSwNP. ${ }^{21}$ Defects in the coordinated

\begin{tabular}{|c|c|c|}
\hline Systemic host factors & Local host factors & Environmental factors \\
\hline 1. Allergy & 1. Anatomic & 1. Microorganisms \\
\hline 2. Immunodeficiency & 2. Neoplasm & (bacteria, fungi, \\
\hline $\begin{array}{l}\text { 3. Mucociliary } \\
\text { dysfunction }\end{array}$ & $\begin{array}{l}\text { 3. Acquired } \\
\text { mucociliary }\end{array}$ & 2. Noxious chemicals \\
\hline 4. Cystic fibrosis & dysfunction & Medications \\
\hline $\begin{array}{l}\text { 5. Granulomatous } \\
\text { diseases }\end{array}$ & $\begin{array}{l}\text { 4. Previous trauma or } \\
\text { surgery }\end{array}$ & \\
\hline 6. GERD & & \\
\hline 7. Aspirin intolerance & & \\
\hline
\end{tabular}

Figure 2 Factors associated with CRS

Note: (C) 2003 Sage Publications. Adapted with permission from Benninger M, et al. Otolaryngol Head Neck Surg. 2003;129(3 suppl):SI-S32. 


\section{- CRS with nasal polyps (CRSwNP)}

- tissue edema, low tumor growth factor- $\beta$ and low T-reg activity

- high tissue eosinophilia and IgE; increased IL-5 and IL-13 (Th2 polarization)

- CRS without nasal polyps (CRSsNP)

- fibrosis, less eosinophilic infiltration

- increased interferon- $\gamma$, tumor growth factor- $\beta$ and T-reg activity (Th1 polarization)

Figure 3 CRS differentiation by inflammatory mediators.

Note: Data from Van Zele T, et al. Differentiation of chronic sinus diseases by measurement of inflammatory mediators. Allergy. 2006;61:I280-I289.

mechanical barrier and/or the innate immune response of the sinonasal epithelium has also been proposed as a mechanism for CRS. This susceptibility may be based on host genetic factors, predisposing some individuals to mechanical barrier failure in the presence of environmental stress. ${ }^{22} \mathrm{CRS}$ is a common problem in patients with Kartagener's syndrome, primary ciliary dyskinesia, and cystic fibrosis. Inability of the sinonasal cilia to transport viscous mucus causes ciliary malfunction leading to CRS.

Epithelial damage and/or host barrier dysfunction may result in colonization of the sinonasal mucosa with Staphylococcus aureus. Subsequent secretion of superantigenic toxins may lead to a skewed Th-2 host inflammatory response with generation of local polyclonal immunoglobulin $\mathrm{E}$ (IgE), promotion of eosinophil survival and mast cell degranulation with alteration of eicosanoid metabolism..$^{23}$ The sum of these local tissue effects may lead to polyp formation. New evidence also implicates the generation of local autoantibodies in perpetuating tissue damage in the most severe forms of CRSwNP. ${ }^{24}$

The role of microbes as causative agents in CRS is not clear, but microbial infection and biofilms may contribute to the propagation of CRS. S. aureus is the most common bacterial pathogen identified in CRS patients in Western countries. ${ }^{25}$ Coagulase-negative Staphylococcus and anaerobic and Gram-negative bacteria are also commonly cultured from CRS patients. ${ }^{26} \mathrm{~A}$ recent prospective study of samples obtained from the middle meatus using the $16 \mathrm{~S}$ ribosomal technique revealed a polymicrobial flora in CRS that was distinct from controls, with a preponderance of anaerobes in CRS. ${ }^{27}$ In post-surgical patients, Pseudomonas, Klebsiella, Enterobacter, and Staphylococcus species predominate. ${ }^{26}$ Bacterial biofilms, which are largely absent in controls, have been recovered from both CRSsNP and CRSwNP patients, with reported rates varying between $30 \%$ and $100 \% .{ }^{28-30}$ While it is not known whether biofilms have a role in the establishment of CRS, it is widely accepted that biofilms facilitate resistance to host defenses and antibiotics, helping to foster recalcitrant disease. Although antibiotics are the most common form of therapy prescribed by physicians for the treatment of CRS, ${ }^{31}$ the precise role of bacteria in CRS pathogenesis remains unclear.

The role of fungi in CRS has been the source of much debate in the last decade. The use of sensitive detection techniques has shown fungi are a ubiquitous intranasal presence in close to $100 \%$ of CRS patients and controls. ${ }^{32}$ Despite this observation, there is a lack of definitive evidence demonstrating that fungal antigens are the primary targets of the mucosal $\mathrm{T}$ or $\mathrm{B}$ cell responses observed in CRS (with the exception of allergic fungal rhinosinusitis)., 2,33

\section{Diagnosis}

CRS is diagnosed based on clinical symptoms and objective evaluation. Symptoms must be present for at least 12 consecutive weeks. Nasal obstruction, facial pressure/ congestion/fullness, discolored nasal discharge, and hyposmia are the signs and symptoms used to diagnose CRS (Figure 1). ${ }^{1}$ Several studies have shown using symptoms alone to diagnose CRS can be nonspecific. ${ }^{34-36}$ Therefore, nasal endoscopy or imaging must also be used to confirm the presence of sinonasal disease to increase the specificity of diagnosis. ${ }^{1}$ Endoscopic findings suggestive of CRS include mucopurulent discharge, nasal polyps or polypoid change, and/or mucosal edema obstructing the middle meatus. A recent study found the addition of endoscopic findings to symptom-based criteria significantly improved diagnostic accuracy of CRS. ${ }^{37}$ 
Computed tomography (CT) is considered the gold standard for imaging in CRS. ${ }^{38,39}$ Findings consistent with CRS include isolated or diffuse mucosal thickening, bone changes, or air-fluid levels. ${ }^{1}$ Magnetic resonance imaging (MRI) does not pose a radiation risk and has improved soft tissue definition over CT scan, but is more expensive. Recent evidence shows a close correlation between $\mathrm{CT}$ and MRI in the staging accuracy of sinonasal disease. ${ }^{40}$

Patients with CRS may frequently present with associated diagnoses of asthma, allergy, dental disease, nasal polyposis, ciliary dyskinesia, cystic fibrosis, and immunodeficiency syndromes. Thus, CRS represents a spectrum of diseases with a range of appropriate treatments. Once the diagnosis of CRS has been established, workup and treatment of patients must be individualized.

\section{Standard treatment}

Although the American Academy of Otolaryngology - Head and Neck Surgery guidelines state CRS should be treated with "maximal medical therapy," there is no such standardized therapy for CRS. This is in part due to the heterogeneity of the disease, which includes CRSwNP, CRSsNP, allergic fungal rhinosinusitis (AFS), and CRS associated with other systemic diseases such as atopy, asthma, cystic fibrosis, and aspirin-exacerbated respiratory disease (AERD). Symptoms may be mild with little effect on quality of life, or may result in significant health problems and loss of productivity. As such, maximal medical therapy is best considered as a philosophical approach, in which CRS in a given individual is treated with a combination of medical strategies best suited for that patient. These treatment strategies include topical and systemic medications. Surgery is performed for recalcitrant disease refractory to medical therapy. This article presents a brief summary of current evidence-based management of CRS. The authors recommend referring to the "European position paper on rhinosinusitis and nasal polyps" by Fokkens et $\mathrm{al}^{33}$ for a more comprehensive review.

\section{Topical medical therapy Topical medication delivery}

The delivery of topical medications has been the subject of recent investigations. Distribution of topical solution to the unoperated sinuses is limited, ${ }^{41}$ with less than $2 \%$ of the total irrigation volume attaining sinus penetration in the setting of CRS with mucosal edema. ${ }^{42}$ Similar findings apply to nebulization, with less than $3 \%$ sinus penetration. ${ }^{43}$ Pre-surgery nasal sprays are the least effective of all application methods. ${ }^{41}$ Thus, ESS is essential to allow effective topical distribution to the sinuses. ${ }^{41,44}$ Singhal et $\mathrm{al}^{45}$ further demonstrated this in a cadaver study which showed improved penetration of irrigant as sinus ostium dimensions increase. A critical diameter of $4.7 \mathrm{~mm}$ was noted to allow maximal penetration in the maxillary and sphenoid sinuses. Head position was found to effect penetration of the frontal sinus, with less penetration seen with the head in neutral position versus a forward-angled position..$^{45}$

Multiple studies suggest large volume devices have the best efficacy following ESS. ${ }^{41,42,44}$ In Harvey and colleagues ${ }^{\text {41 }}$ experiment using Gastroview irrigation in cadavers, distribution was significantly higher with use of a neti pot or squeeze bottle versus a pressurized spray.

\section{Intranasal saline}

Numerous studies have been performed to evaluate the efficacy of saline nasal irrigation in relieving CRS symptoms and improving clinical outcomes. Harvey et $\mathrm{al}^{46}$ published a meta-analysis in 2007, which identified eight randomized controlled trials in which saline was compared with either no treatment, placebo, or as a treatment adjunct. The authors concluded that saline nasal irrigation is beneficial in relieving symptoms of CRS when used as the sole modality of treatment, as well as a treatment adjunct ${ }^{46}$ Rudmik et a ${ }^{47}$ recently published an evidence-based review of topical therapies in the management of CRS including eight randomized controlled trials (RCTs) and one meta-analysis evaluating saline. They recommended sinonasal saline irrigations as an adjunct to other topical therapy strategies due to improved symptoms and health-related quality of life, an excellent safety profile, and preponderance of benefit over harm. ${ }^{47}$

Intranasal saline has been shown to be beneficial in both unoperated and postoperative patients. High volume, low pressure irrigation devices have demonstrated superiority over other methods of delivery. Pynnonen et $\mathrm{al}^{48}$ evaluated the efficacy of large volume, low-pressure saline irrigation versus saline spray in non-postoperative patients in an RCT. The irrigation group had improved symptoms over the spray group as measured by the Sino-Nasal Outcome Test (SNOT-20). ${ }^{48}$ Liang et a ${ }^{49}$ performed a randomized trial of large-volume saline irrigation in CRS patients post-ESS and found significant benefit in symptoms and endoscopy scores in patients with mild CRS. However, there was no significant difference in those with severe CRS. ${ }^{49}$

Other studies evaluating the effect of intranasal saline on endoscopic appearance in CRS have been performed. A single-blinded RCT in which patients post-ESS performed unilateral nasal douching demonstrated improved discharge 
and edema at 3 weeks, but no difference in adhesions or crusting. There were no differences in nasal endoscopy noted at 3 months. ${ }^{50}$ One criticism of this study is the lowvolume saline irrigation protocol $(2 \mathrm{~mL}$ atomized 3 times daily) used.

Table 1 lists ten RCTs evaluating the impact of intranasal saline on clinical outcomes in CRS patients, with type of saline (hypertonic versus isotonic), delivery method, and outcomes noted. Both pre-surgical and post-ESS studies were included. All seven pre-surgical RCTs ${ }^{48,51-55,57}$ demonstrated improved symptoms and health-related quality of life, although the study by Heatley et $\mathrm{al}^{53}$ showed no difference between reflexology as placebo and saline irrigation groups. Of the three post-ESS studies, two RCTs showed improved outcomes with intranasal saline, ${ }^{49,50}$ while the third showed no difference in patient symptom scores between normal saline, hypertonic saline, and no irrigation groups. ${ }^{56}$ Overall, saline nasal irrigations are well tolerated. Side effects are uncommon, but include nasal discomfort, drainage, epistaxis, headache, and otalgia. ${ }^{46}$ Most studies suggest symptom and health-related quality of life improvement with usage.
The superiority of hypertonic versus isotonic saline remains unclear.

\section{Topical steroids}

Glucocorticoids are a mainstay of CRS treatment. Steroids reduce eosinophil viability and activation ${ }^{58,59}$ and may indirectly reduce the secretion of chemotactic cytokines by nasal mucosa and polyp epithelial cells. ${ }^{59}$ Topical sinonasal steroids are used to achieve these anti-inflammatory effects on a local level, thereby minimizing systemic effects. They have an excellent safety profile and are well tolerated over long periods of time.

Topical steroids can be subdivided into conventional US Food and Drug Administration (FDA)-approved formulations for nasal use, and nonconventional formulations lacking FDA approval specifically for nasal therapy. Conventional FDAapproved solutions available by metered-dose, low-volume topical sprays include fluticasone proprionate, mometasone furoate, ciclesonide, budesonide, flunisolide, fluticasone furoate, beclomethasone dipropionate monohydrate, and triamcinolone acetonide. ${ }^{47}$ Nonconventional off-label use

Table I Randomized controlled trials evaluating intranasal saline in CRS

\begin{tabular}{|c|c|c|c|c|c|}
\hline Author & Year & Outcome measures & Treatment groups & Delivery method & Results \\
\hline Shoseyov et $\mathrm{al}^{51}$ & 1998 & $\begin{array}{l}\text { Symptom and radiological } \\
\text { scores in children }\end{array}$ & $3.5 \% \mathrm{HTS}$ versus ITS & I mL nasal drops & $\begin{array}{l}\text { Improved cough score in HTS } \\
\text { group; other scores similar }\end{array}$ \\
\hline Bachmann et $\mathrm{al}^{52}$ & 2000 & $\begin{array}{l}\text { Symptom, endoscopic, } \\
\text { mucociliary clearance, } \\
\text { rhinometry and } \\
\text { olfactometry scores }\end{array}$ & HTS versus ITS & $200 \mathrm{~mL}$ irrigator & $\begin{array}{l}\text { Improved symptom scores in both } \\
\text { groups; no difference between } \\
\text { groups }\end{array}$ \\
\hline Heatley et $\mathrm{al}^{53}$ & 2001 & $\begin{array}{l}\text { SNOT-20 and RSOM3I } \\
\text { scores }\end{array}$ & $\begin{array}{l}2.7 \% \text { HTS via bulb syringe } \\
\text { versus irrigation pot } \\
\text { versus reflexology placebo }\end{array}$ & $\begin{array}{l}\text { Bulb syringe versus } \\
\text { irrigator }\end{array}$ & $\begin{array}{l}\text { Improved scores in all groups, with } \\
\text { no difference between groups and } \\
\text { placebo }\end{array}$ \\
\hline Rabago et al ${ }^{54}$ & 2002 & $\begin{array}{l}\text { QoL, RSDI, and SIA } \\
\text { scores }\end{array}$ & $2 \%$ HTS versus control & $300 \mathrm{~mL}$ nasal cup & $\begin{array}{l}\text { Improved RSDI and SIA in saline } \\
\text { group versus controls }\end{array}$ \\
\hline Cordray et $\mathrm{al}^{55}$ & 2005 & QoL scores & $\begin{array}{l}\text { HTS versus triamcinolone } \\
\text { versus ITS }\end{array}$ & Nasal spray & $\begin{array}{l}\text { Improvements in steroid and HTS } \\
\text { groups }\end{array}$ \\
\hline Pinto et $\mathrm{al}^{56}$ & 2006 & Symptoms post-ESS & $\begin{array}{l}\text { ITS versus HTS versus } \\
\text { control }\end{array}$ & Nasal spray & $\begin{array}{l}\text { No symptom improvement in ITS } \\
\text { or HTS group over control. More } \\
\text { pain in HTS group }\end{array}$ \\
\hline $\begin{array}{l}\text { Hauptman } \\
\text { and Ryan }\end{array}$ & 2007 & $\begin{array}{l}\text { Acoustic rhinometry, } \\
\text { saccharine clearance } \\
\text { times, symptoms }\end{array}$ & ITS versus HTS & Nasal spray & $\begin{array}{l}\text { ITS and HTS improved saccharine } \\
\text { clearance times and symptoms of } \\
\text { nasal stuffiness. ITS improved nasal } \\
\text { patency }\end{array}$ \\
\hline Pynnonen et $\mathrm{al}^{48}$ & 2007 & $\begin{array}{l}\text { SNOT-20 score, } \\
\text { symptom frequency, } \\
\text { and medication usage }\end{array}$ & $\begin{array}{l}\text { ITS via large volume } \\
\text { irrigation versus spray }\end{array}$ & $\begin{array}{l}\text { Large volume } \\
\text { irrigation versus } \\
\text { spray }\end{array}$ & $\begin{array}{l}\text { Improved SNOT-20 score and } \\
\text { symptom frequency in irrigation } \\
\text { over spray group }\end{array}$ \\
\hline Liang et $\mathrm{al}^{49}$ & 2008 & $\begin{array}{l}\text { Symptom and endoscopy } \\
\text { scores post-ESS }\end{array}$ & $\begin{array}{l}\text { Buffered ITS + medical } \\
\text { treatment versus medical } \\
\text { treatment }\end{array}$ & $\begin{array}{l}500 \mathrm{~mL} \text { pulsatile } \\
\text { irrigator }\end{array}$ & $\begin{array}{l}\text { Improved endoscopy and symptom } \\
\text { scores in irrigation group with mild } \\
\text { CRS only }\end{array}$ \\
\hline Freeman et $\mathrm{al}^{50}$ & 2008 & $\begin{array}{l}\text { Endoscopy scores } \\
\text { post-ESS }\end{array}$ & $\begin{array}{l}\text { ITS + medical treatment } \\
\text { versus medical treatment }\end{array}$ & $2 \mathrm{~mL}$ atomized & $\begin{array}{l}\text { Improved endoscopic appearance at } \\
3 \text { weeks; no difference at } 3 \text { months }\end{array}$ \\
\hline
\end{tabular}

Abbreviations: CRS, chronic rhinosinusitis; HTS, hypertonic saline; ITS, isotonic saline; SNOT-20, Sino-Nasal Outcome Test; RSOM3I, rhinosinusitis outcomes measure; QoL, quality of life; RSDI, rhinosinusitis disability index; SIA, symptoms severity assessment; ESS, endoscopic sinus surgery. 
of steroid nasal irrigation is growing in popularity with rhinologists, as higher volume and higher steroid concentrations can be used. Large volume nasal irrigation with budesonide, a potent anti-inflammatory corticosteroid with a high ratio of topical-to-systemic activity, has become increasingly popular in patients with CRS and has been shown to be efficacious and well tolerated by patients. ${ }^{60,61}$

Fokkens et $\mathrm{al}^{33}$ performed a recent systematic review of RCTs for evidence of benefit in treating CRSsNP with topical corticosteroids, which included eleven studies. Of these, data from five studies could be pooled for meta-analysis, demonstrating significant benefit in the topical steroid group when compared with placebo. When the surgical state of the patients was assessed on subgroup analysis, only patients with prior surgery for CRSsNP had symptom improvement. There was no improvement for patients without surgery. ${ }^{33}$

Topical steroids are also effective in CRSwNP. Fokkens et $\mathrm{al}^{33}$ performed a separate systematic review of RCTs for CRSwNP treated with topical corticosteroids, which yielded 38 studies. Meta-analysis showed intranasal steroids, when compared to placebo, improved symptoms, polyp size, polyp recurrence, and nasal airflow. In the subgroup analysis, patients with sinus surgery responded to topical steroids greater than patients without sinus surgery in polyp size reduction. ${ }^{33}$

Rudmik et $\mathrm{al}^{47}$ identified five meta-analyses evaluating the role of conventional FDA-approved topical nasal steroid therapy on clinical outcomes, combining CRSsNP and CRSwNP. Four of the five meta-analyses demonstrated significant improvement in symptoms, endoscopic appearance, or both. ${ }^{62-65}$ The meta-analysis by Kalish et al ${ }^{66}$ combined the results of six RCTs to evaluate the effect of topical steroid therapy in CRSsNP, and was the only study finding insufficient evidence to demonstrate a significant benefit with treatment. However, the more recent meta-analysis of topical steroid therapy in CRSsNP by Snidvongs et $\mathrm{al}^{65}$ included ten RCTs and showed improved overall symptom scores with topical steroid therapy.

There is a large body of evidence demonstrating the efficacy of conventional topical steroid therapy in both patients with CRSsNP and CRSwNP, with improved symptoms, endoscopic appearance, and reduced polyp size. Side effects are uncommon, but include epistaxis, dry nose, nasal irritation, headache, and cough. ${ }^{33,47}$

Limited high-quality data exists regarding off-label steroid nasal irrigation. One RCT by Rotenberg et al, ${ }^{67}$ compared saline irrigation, saline plus budesonide spray (separately), and saline plus budesonide spray (combined) in patients with
AERD post-ESS. All groups showed improved disease status compared with baseline, but there was no difference between groups. ${ }^{67}$ Further studies are indicated to determine potential benefits and side-effects of off-label topical steroid usage.

\section{Topical antibiotics}

The goal of topical antibiotic therapy is local delivery of high drug concentrations while reducing systemic effects. However, the efficacy of topical antibiotics has not been proven. Four placebo-controlled RCTs of topical antibiotics in CRS have been performed (Table 2). ${ }^{6-71}$ Three RCTs show no benefit to topical antibiotics over saline; however, none of these investigations employed large volume positive pressure irrigation. The first study by Sykes et al ${ }^{68}$ evaluated topical sprays with neomycin, while the others used nebulized tobramycin and bacitracin/colimycin, respectively. ${ }^{69,70}$ One possible reason for lack of efficacy in these studies is inadequate sinus penetration with the delivery methods used. A systematic review by Lim et $\mathrm{al}^{72}$ similarly concluded that the evidence for use of topical antibacterials is limited. The highest level of evidence currently exists for studies using postsurgical patients and culture-directed therapy. ${ }^{72}$

Jervis-Bardy et al ${ }^{71}$ recently published a double-blinded, placebo-controlled RCT evaluating topical mupirocin irrigations versus saline on bacterial cultures, symptoms, and endoscopy scores in post-ESS patients with a pre-treatment $S$. aureus positive culture. They found $0 \%$ versus $88.9 \%$ $S$. aureus-negative sinonasal culture at 1 month in the saline versus mupirocin groups, respectively. Endoscopy scores at 1 month were significantly improved in the mupirocin group compared with the saline group; however, there were no significant differences in symptoms between groups. ${ }^{71}$

Recent investigations of topical antibiotics in CRS have been directed toward biofilms. The topical application of mupirocin, ciprofloxacin, and vancomycin on established in-vitro biofilms of $S$. aureus isolated from patients with CRS was evaluated by Ha et al. ${ }^{73}$ Their study showed mupirocin was capable of reducing biofilm mass by greater than $90 \%$ at safe concentrations. Ciprofloxacin and vancomycin were largely ineffective at concentrations within safe dosage ranges. $^{73}$ Thus, topical antibiotics have potential efficacy; however, there is currently a low level of evidence for their use.

\section{Emerging strategies in topical therapy}

The treatment of biofilms is a subject under current investigation. In addition to topical antibiotics, newer 
Table 2 Randomized controlled trials evaluating topical antibiotics in CRS

\begin{tabular}{|c|c|c|c|c|c|}
\hline Author & Year & Outcome measures & Treatment groups & Treatment protocol & Result \\
\hline Sykes et $a^{68}$ & 1986 & $\begin{array}{l}\text { Symptoms, bacterial } \\
\text { culture, sinus } \\
\text { radiograph, saccharin } \\
\text { clearance, allergy testing }\end{array}$ & $\begin{array}{l}\text { Dexamethasone/ } \\
\text { tramazoline/neomycin } \\
\text { versus dexamethasone/ } \\
\text { tramazoline versus placebo }\end{array}$ & $\begin{array}{l}\text { Nasal spray } \\
\text { QID } \times 4 \text { weeks }\end{array}$ & $\begin{array}{l}\text { Improvements in both treatment } \\
\text { groups over placebo; no difference } \\
\text { with addition of topical antibiotic }\end{array}$ \\
\hline $\begin{array}{l}\text { Desrosiers } \\
\text { et } \mathrm{al}^{69}\end{array}$ & 2001 & $\begin{array}{l}\text { Symptoms, QoL, } \\
\text { endoscopy }\end{array}$ & $\begin{array}{l}\text { Tobramcyin in saline } \\
\text { versus saline }\end{array}$ & $\begin{array}{l}\text { Large-particle nebulizer } \\
\text { TID } \times 4 \text { weeks }\end{array}$ & $\begin{array}{l}\text { Improvements in both groups; no } \\
\text { benefit of tobramycin over saline }\end{array}$ \\
\hline Videler et $\mathrm{al}^{70}$ & 2008 & $\begin{array}{l}\text { Symptoms, QoL, } \\
\text { endoscopy }\end{array}$ & $\begin{array}{l}\text { Bacitracin/colimycin versus } \\
\text { placebo }\end{array}$ & $\begin{array}{l}\text { RhinoFlow nebulizer } \\
\text { BID + oral levofloxacin }\end{array}$ & $\begin{array}{l}\text { Improvements in both groups, with } \\
\text { no benefit over placebo }\end{array}$ \\
\hline $\begin{array}{l}\text { Jervis-Bardy } \\
\text { et } \mathrm{al}^{71}\end{array}$ & 2012 & $\begin{array}{l}\text { Bacterial culture, } \\
\text { symptoms, endoscopy } \\
\text { post-ESS }\end{array}$ & $\begin{array}{l}\text { Mupirocin versus saline in } \\
\text { Staphylococcus } \\
\text { aureus-positive patients }\end{array}$ & $\begin{array}{l}240 \mathrm{~mL} \text { irrigation } \\
\text { BID } \times I \text { month }\end{array}$ & $\begin{array}{l}\text { Staphylococcus aureus culture } \\
\text { negativity in } 88.9 \% \text { of mupirocin } \\
\text { versus } 0 \% \text { of saline group; improved } \\
\text { early endoscopic score in mupirocin } \\
\text { group over saline; no difference in } \\
\text { symptoms between groups }\end{array}$ \\
\hline
\end{tabular}

Abbreviations: CRS, chronic rhinosinusitis; QID, four times daily; QoL, quality of life; TID, three times daily; BID, twice daily; ESS, endoscopic sinus surgery.

research has been directed toward surfactants, which reduce water surface tension and may help to dissolve biofilms. ${ }^{74}$ Baby shampoo nasal irrigation has been studied against biofilms in symptomatic postoperative patients. One percent baby shampoo in normal saline was found to be the optimal concentration for inhibition of Pseudomonas species biofilm formation in vitro. Using this solution twice daily for 4 weeks, nearly $50 \%$ of patients experienced an overall improvement in symptoms, with $60 \%$ noting improvement of thick mucus and postnasal drainage. ${ }^{75}$

Other novel nasal irrigation additives include xylitol and sodium hypochlorite. Xylitol is a naturally occurring sugar substitute commonly used in chewing gum, which has been shown to reduce dental caries. ${ }^{76} \mathrm{~A}$ recent RCT evaluating xylitol in water as a nasal irrigant in CRS showed improved sinonasal symptoms over saline and was well tolerated. ${ }^{77}$ Sodium hypochlorite is a bleaching and disinfecting agent effective against $S$. aureus and Pseudomonas aeruginosa. Nasal lavage with $0.05 \%$ sodium hypochlorite in saline twice daily for 3 months was well tolerated in patients and showed a significant improvement in symptoms and endoscopic appearance. ${ }^{78}$

\section{Systemic medical therapy Oral steroids}

Oral corticosteroids have been used in patients with CRSwNP for many years due to a positive effect on nasal polyp size, symptoms, and nasal expiratory peak flow. A recent systematic review by Poetker et al ${ }^{79}$ identified five RCTs supporting the use of oral steroids in the short-term management of CRSwNP (Table 3).

Hissaria et $\mathrm{al}^{80}$ randomized $41 \mathrm{CRSwNP}$ patients to receive $50 \mathrm{mg}$ of prednisolone or placebo for 14 days.
The steroid group showed a statistically significant improvement over placebo in symptoms and quality of life outcome measures, in addition to nasal endoscopy and MRI. Kirtsreesakul et al ${ }^{83}$ also found statistically significant subjective and objective improvement in prednisolone-treated patients over controls. Vaidyanathan et $\mathrm{al}^{84}$ again showed statistically significant subjective and objective improvement in prednisolone-treated patients over controls. Interestingly, their outcomes also included markers of adrenal suppression and bone turnover. They found overnight urinary cortisol was suppressed to $50 \%$ of baseline and adrenocorticotropic hormone-stimulated serum cortisol suppressed to $86 \%$ of baseline at the end of the treatment period ( 2 weeks) in the steroid arm. They also showed a transient decrease in markers of osteoblast activity at 2 weeks. Both of these effects were no longer evident at 10 and 28 weeks. ${ }^{84}$ Finally, the RCT by Wright and Agrawal ${ }^{85}$ demonstrated the beneficial effects of perioperative systemic steroids in patients undergoing ESS for CRSwNP. They found a higher percentage of severely inflamed sinonasal mucosa and more technically difficult surgery in patients not pretreated with systemic steroids. In addition, endoscopic assessment of patients treated postoperatively with systemic steroids revealed clinically healthier cavities compared with controls. ${ }^{85}$

There is limited evidence supporting oral steroid therapy in CRSsNP. A systematic review by Lal and Hwang ${ }^{86}$ revealed no RCTs of oral steroids in CRSsNP or any clinical study employing systemic corticosteroids alone. They identified two retrospective ${ }^{87,88}$ and one prospective study ${ }^{89}$ using oral steroids in combination with antibiotics and nasal steroids to treat CRSsNP. Tosca et al ${ }^{89}$ prospectively studied children with allergic and nonallergic CRS and asthma, showing oral and intranasal steroids with oral antibiotics improved endoscopy 
Table 3 Randomized controlled trials evaluating oral steroids in CRSwNP

\begin{tabular}{|c|c|c|c|c|c|}
\hline Author & Year & $\mathbf{N}$ & Outcome measures & Treatment groups & Results \\
\hline Hissaria et a $\left.\right|^{80}$ & 2006 & 41 & $\begin{array}{l}\text { Symptoms, MRI, } \\
\text { endoscopy }\end{array}$ & $\begin{array}{l}\text { Prednisolone } 50 \mathrm{mg} \text { daily versus } \\
\text { placebo } \times 14 \text { days }\end{array}$ & $\begin{array}{l}\text { Improved symptoms, MRI and } \\
\text { endoscopic appearance in steroid } \\
\text { group versus control }\end{array}$ \\
\hline Kroflic et a ${ }^{81}$ & 2006 & 40 & $\begin{array}{l}\text { Symptoms, } \\
\text { endoscopy, histology, } \\
\text { intraoperative bleeding }\end{array}$ & $\begin{array}{l}\text { Methylprednisolone } 1 \mathrm{mg} / \mathrm{kg} \\
\text { daily versus nasal furosemide } \times \\
7 \text { days pre-ESS }\end{array}$ & $\begin{array}{l}\text { Improved symptoms and polyp } \\
\text { size in both groups with no } \\
\text { clinical difference between groups }\end{array}$ \\
\hline Van Zele et al ${ }^{82}$ & 2010 & 47 & $\begin{array}{l}\text { Endoscopy, } \\
\text { rhinometry, } \\
\text { symptoms, SEC, nasal } \\
\text { IL-5, IgE, MMP-9, ECP }\end{array}$ & $\begin{array}{l}\text { Methylprednisolone taper over } \\
20 \text { days versus oral doxycycline } \times \\
20 \text { days versus placebo }\end{array}$ & $\begin{array}{l}\text { Improved polyp size, nasal } \\
\text { patency, inflammatory markers } \\
\text { and symptoms in steroid group } \\
\text { versus placebo }\end{array}$ \\
\hline Kirtsreesakul et a ${ }^{83}$ & 2011 & 109 & $\begin{array}{l}\text { Symptoms, } \\
\text { rhinometry, } \\
\text { endoscopy }\end{array}$ & $\begin{array}{l}\text { Prednisolone } 50 \mathrm{mg} \text { daily versus } \\
\text { placebo } \times 14 \text { days }\end{array}$ & $\begin{array}{l}\text { Improved symptoms, nasal } \\
\text { patency and polyp size in steroid } \\
\text { group versus control }\end{array}$ \\
\hline Vaidyanathan et a ${ }^{84}$ & 2011 & 60 & $\begin{array}{l}\text { Endoscopy, symptoms, } \\
\text { QoL, rhinometry, } \\
\text { CRP, EDN }\end{array}$ & $\begin{array}{l}\text { Prednisolone } 25 \mathrm{mg} \text { daily versus } \\
\text { placebo } \times 14 \text { days, both followed } \\
\text { by intranasal fluticasone }\end{array}$ & $\begin{array}{l}\text { Improved polyp size, symptoms, } \\
\text { QoL, serum EDN, and CRP in } \\
\text { steroid group versus control }\end{array}$ \\
\hline
\end{tabular}

Abbreviations: CRSwNP, chronic rhinosinusitis with nasal polyposis; MRI, magnetic resonance imaging; ESS, endoscopic sinus surgery; SEC, serum eosinophil count; IL-5, interleukin 5; IgE, immunoglobulin E; MMP-9, matrix metalloproteinase-9; ECP, eosinophilic cationic protein; QoL, quality of life; CRP, C-reactive protein; EDN, eosinophil-derived neurotoxin.

and decreased inflammatory infiltrate. The retrospective study by Subramanian et al ${ }^{87}$ included both CRSwNP and CRSsNP, but found the CRSsNP patients had better outcomes with a multidrug regimen including oral steroids. Lal et a ${ }^{88}$ noted improved symptom resolution in CRSsNP compared with all CRS patients in a retrospective study. Due to limited low level evidence of subjective and objective improvement, oral steroids in CRSsNP remains optional. ${ }^{79,86}$

Rupa et a $\mathrm{l}^{90}$ published the only RCT evaluating post-ESS oral steroids in patients with AFS. Twenty-four patients were randomized to receive prednisolone or placebo, while patients in both arms received concurrent ranitidine, itraconazole, and fluticasone nasal spray. At 12 weeks, patients in the steroid arm had complete resolution of symptoms and polypoid disease on endoscopy, whereas only one patient in the placebo arm had full symptom and endoscopic resolution of disease. ${ }^{90}$ Two prospective studies found oral steroids similarly beneficial in AFS. ${ }^{91,92}$

Systemic corticosteroids have a significant side effect profile, which increases with dose and duration of treatment. Patients should be counseled regarding the possible negative effects on bone mineral density, hyperglycemia, weight gain, early cataract formation, pituitary-hypothalamic axis suppression, sleep disturbance, and exacerbation of psychiatric conditions. ${ }^{93}$ Given the natural history of CRS requiring ongoing treatment over long periods of time, the short-lived benefits of systemic steroids must be balanced with the longterm potential side effects. The preponderance of benefit over harm is better supported by trials in CRSwNP than in CRSsNP, where evidence is insufficient.

\section{Oral antibiotics}

Oral antibiotics are the most commonly prescribed medication for $\mathrm{CRS}^{31}$ and remain a mainstay of treatment. Despite this, there is a surprising paucity of quality data regarding efficacy. There is level 2 evidence for short-term treatment of CRSsNP in exacerbations with a positive culture based on two RCTs, ${ }^{94,95}$ though no placebo-controlled studies have been performed. In general, first-line antibiotics for CRS exacerbations include amoxicillin-clavulanate and second- or third-generation cephalosporins. The respiratory quinolones are helpful second-line agents for refractory cases (Figure 4) ${ }^{96}$

The increasing prevalence of $S$. aureus and antimicrobial resistance in CRS highlights the importance of using culturedirected antimicrobial therapy with the goal of minimizing

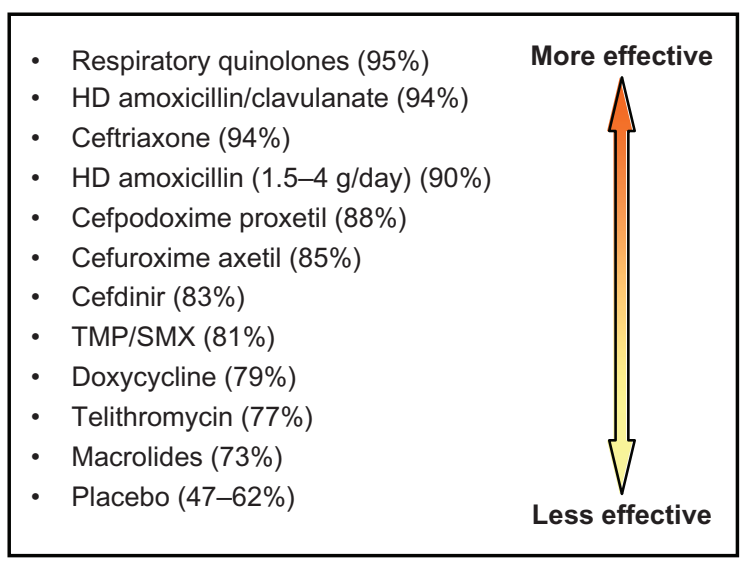

Figure 4 Efficacy of antibiotics in CRS.

Note: Data from Anon JB, et al. Otolaryngol Head Neck Surg. 2004; I30(I Suppl): I-45. Abbreviations: HD, high dose; TMP/SMX, trimethoprim-sulfamethoxazole. 
future resistance patterns. ${ }^{97}$ Bhattacharyya and Kepnes ${ }^{98}$ analyzed 701 bacterial isolates among 392 culture samples from patients with CRS, and concluded that antibiotic resistance seems to be emerging for erythromycin at a rate higher than for other antibiotics such as methicillin, clindamycin, gentamicin, tetracycline, sulfamethoxazole, and levofloxacin. As the emergence of antibiotic resistance has increased the failure rate of empiric treatment, culture-directed therapy has become the standard of care when treating CRS with antibiotics. ${ }^{99}$

Based on the emerging pattern of drug-resistance, it is not surprising that macrolides have often been the antibiotic of choice in long-term therapy of CRS. Macrolides have anti-inflammatory and immune-modulatory effects similar to glucocorticoids. Knowledge of this dates back to the publication of long-term, low-dose erythromycin treatment of diffuse panbronchiolitis, which improved concomitant CRS. ${ }^{100}$

Two placebo-controlled RCTs have studied the effect of a macrolide on signs, symptoms, and quality of life in CRS over a period of 12 weeks. ${ }^{101,102}$ While the first investigation showed clinical efficacy of roxithromycin with a response rate of $67 \%$ in the treatment group versus $22 \%$ in the placebo group,${ }^{101}$ the second study showed no significant difference between azithromycin and placebo groups. ${ }^{102}$ The discrepancy in these results may be secondary to divergent CRS patient populations, as the studies had different inclusion criteria, and macrolides have been found to be more effective in certain patient populations. For example, normal $\operatorname{IgE}$ levels are associated with a higher response rate to macrolide treatment versus elevated IgE levels, ${ }^{101,103,104}$ which highlights the need to individualize CRS therapy.

Doxycycline is another antibiotic with anti-inflammatory properties. In a multicenter double-blind placebo-controlled trial, both methylprednisolone and doxycycline for 20 days decreased polyp size compared with placebo in CRSwNP. $^{82}$

Long-term, low-dose antibacterial treatment presents the greatest concern for the emergence of resistant bacterial strains. In a placebo-controlled RCT exposing oral streptococcal flora of healthy volunteers to macrolides, antibiotic use was shown to be the most important driver of antibiotic resistance. ${ }^{105}$ Consideration should also be given to the well known adverse effects of systemic antibiotics, including abdominal pain, diarrhea, Clostridium difficile colitis, anaphylaxis, rash, tendinitis, and tendon rupture. Some of these effects are exacerbated with concomitant oral steroid usage. Patient counseling regarding these potential effects is recommended prior to prescribing oral antibiotics.

\section{Antifungals}

Fungi have been postulated to be a potential cause of CRS, ${ }^{32}$ therefore oral and topical antifungal agents have been explored in its management. Although an early RCT found topical amphotericin to be beneficial, ${ }^{106}$ multiple follow-up RCTs evaluating the efficacy of topical amphotericin in CRS have not supported its use. ${ }^{107-109} \mathrm{~A}$ recent systematic review of the literature with meta-analysis was performed by Sacks et $\mathrm{al}^{110}$ to assess the potential advantage of either topical or systemic antifungal therapy in the symptomatic treatment of CRS. This yielded five studies investigating topical and one study investigating systemic antifungals, all of which were RCTs. Pooled meta-analysis showed no statistically significant benefit of topical or systemic antifungals over placebo. Interestingly, symptoms scores statistically favored placebo and adverse event reporting was higher in the antifungal group. ${ }^{110}$

\section{Emerging strategies in systemic therapy Leukotriene antagonists}

Leukotriene antagonists, such as montelukast, zafirlukast, and zileuton, have been evaluated in numerous studies involving patients with CRSwNP and AERD. Results have been mixed. Several uncontrolled open-label studies suggest benefit of antileukotrienes on symptomatology, ${ }_{111}^{11}$ nasal polyp, and CT scores. ${ }^{112}$ However, data from RCTs do not consistently support the benefit of antileukotriene therapy in all CRS patients. Mostafa et al ${ }^{113}$ randomized $40 \mathrm{CRSwNP}$ patients to either $10 \mathrm{mg}$ monteleukast or beclomethasone nasal spray daily for 1 year, finding no differences in disease relapse frequency and greater overall symptom improvement with beclomethasone. Another RCT separated $38 \mathrm{CRSwNP}$ patients into two groups. The first received oral prednisolone for 14 days plus budesonide nasal spray for 8 weeks. The second received the same treatment with the addition of $10 \mathrm{mg}$ oral monteleukast. The addition of monteleukast failed to show a significant effect on the overall symptom score, although reduction in headache, facial pain, and sneezing reached significance. ${ }^{114}$

\section{Anti-lgE therapy}

In CRSwNP, total IgE levels in nasal secretions, nasal polyp homogenisates and blood serum have been shown to be higher than in controls. ${ }^{115}$ Omalizumab is a recombinant humanized monoclonal antibody that selectively binds to human $\operatorname{IgE}$ and reduces levels in serum and tissue, which is approved for patients with moderate to severe or severe allergic asthma. 
Though anecdotal reports showed beneficial effects of omalizumab in CRSwNP, a small RCT showed no significant difference in sinus opacification or SNOT-20 scores. ${ }^{116}$ This RCT, however, was underpowered. Further investigation regarding anti-IgE therapy may be warranted.

\section{Anti-IL-5 therapy}

Abundant eosinophilia is also found in the majority of patients with CRSwNP. IL-5, produced by Th-2 and mast cells, is a key player in eosinophil growth, recruitment, and activation. IL-5 has been found to be significantly increased in patients with nasal polyps compared with controls. Mepolizumab and reslizumab are humanized anti-IL-5 monoclonal antibodies currently undergoing investigation in the treatment of CRSwNP. A double-blind, placebo-controlled RCT including 30 patients with severe nasal polyposis refractory to corticosteroid therapy found two single intravenous injections of mepolizumab achieved a statistically significant reduction in nasal polyp size for at least 1 month when compared with placebo. In addition, significantly less sinus opacification was observed in the treatment arm. ${ }^{117}$ Another double-blind, placebo-controlled RCT showed a single infusion of reslizumab in CRSwNP patients had no significant improvement on symptoms or nasal polyp score over controls. ${ }^{118}$ Anti-IL-5 therapy is an interesting area for future research.

\section{Aspirin desensitization}

Aspirin desensitization for patients with AERD has been evaluated in several case series and prospective studies; however, no RCTs have been performed. Forer et al ${ }^{119}$ found significantly improved symptoms in patients undergoing aspirin desensitization, though objective results were not significant. Stevenson et al ${ }^{120}$ also noted significantly improved nasal symptoms in 25 AERD patients following aspirin desensitization. Rozsasi et al ${ }^{121}$ allocated AERD patients to either take $100 \mathrm{mg}$ or $300 \mathrm{mg}$ aspirin daily. After 1 year of therapy, all patients in the $100 \mathrm{mg}$ group had developed recurrent nasal polyps, whereas no patient in the $300 \mathrm{mg}$ group had recurrent nasal polyps on endoscopy. ${ }^{121}$ Risks of oral aspirin desensitization include severe hypersensitivity, anaphylaxis, and gastrointestinal side effects.

\section{Endoscopic sinus surgery}

Numerous large, well organized prospective studies have shown endoscopic sinus surgery (ESS) to be safe and effective in managing both patients with CRSsNP and CRSwNP who have failed adequate control with medical treatment. ${ }^{122,123}$ The goals of ESS include eradication of inflammatory tissue and osteitis, implementation of adequate drainage and ventilation pathways, restoration of mucociliary function, creation of access for topical medication, reduction of acute exacerbations and systemic medication usage, and quality of life improvement. A review of 21 studies including 2070 patients with CRS found all symptoms were improved after a mean period of 13 months following ESS, with nasal obstruction improving the most, facial pain and postnasal discharge demonstrating moderate improvements, and headache improving the least. ${ }^{124}$ Improvements in generic and disease-specific quality of life with surgery have also been shown. ${ }^{122}$ ESS significantly decreases antibiotic utilization in CRSwNP and CRSsNP. ${ }^{125}$ In a prospective multi-institutional study comparing medical and surgical therapy for CRS, patients electing ESS experienced significantly higher levels of improvement based on two validated disease-specific quality-of-life instruments. ${ }^{126}$ Approximately 15\%-20\% of patients require revision sinus surgery. Previous revision surgery, extensive polyps, bronchial asthma, aspirin intolerance, and cystic fibrosis are predictors of patients who may require revision surgery. ${ }^{123}$

\section{Conclusion}

CRS is a complex condition with profound effects on patient quality of life and health care expenditure. Its management continues to challenge both patients and health care providers. There is now a preponderance of evidence supporting the concept that inflammation, as opposed to infection, is the dominant etiologic factor in CRS. While systemic antibiotics and steroids were a mainstay of treatment in the past, the focus is now shifting toward topical therapy, improved nasal delivery systems, and novel antiinflammatory therapies. Potential development of microbial resistance remains a salutary concern in patients treated with repeated or prolonged antimicrobial agents. Immune modulators, such as anti-IgE and anti-IL5 antibodies, are promising areas of ongoing research. Surgery continues to play an important role in management of recalcitrant disease, resulting in quality-of-life improvement and assisting in aggressive medical management. The complex and diverse nature of CRS requires an individualized approach to both medical and surgical management in a multidisciplinary setting. 


\section{Disclosure}

The authors have nothing to disclose, nor any conflicts of interest.

\section{References}

1. Rosenfeld RM, Andes D, Bhattacharyya, et al. Clinical practice guideline: adult sinusitis. Otolaryngol Head Neck Surg. 2007;137(Suppl 3): S1-S31.

2. Benninger MS, Ferguson BJ, Hadley JA, et al. Adult chronic rhinosinusitis: definitions, diagnosis, epidemiology, and pathophysiology. Otolaryngol Head Neck Surg. 2003;129(Suppl 3):S1-S32.

3. Van Zele T, Claeys S, Gevaert P, et al. Differentiation of chronic sinus diseases by measurement of inflammatory mediators. Allergy. 2006;61(1):1280-1289.

4. Lee LN, Bhattacharyya N. Regional and specialty variations in the treatment of chronic rhinosinusitis. Laryngoscope. 2011;121(5): 1092-1097.

5. Pleis JR, Lucas JW, Ward BW. Summary health statistics for US adults: National Health Interview Survey, 2008. Vital Health Stat 10 2009;242:1-157.

6. Anon JB, Jacobs MR, Poole MD, et al. Antimicrobial treatment guidelines for acute bacterial rhinosinusitis. Otolaryngol Head Neck Surg. 2004;130(Suppl 1):1-45.

7. Collins JG. Prevalence of selected chronic conditions: United States, 1990-1992. Vital Health Stat 10. 1997;194:1-89.

8. Blackwell DL, Collins JG, Coles R. Summary health statistics for US adults: National Health Interview Survey, 1997. Vital Health Stat 10. 2002;205:1-109.

9. Shashy RG, Moore EJ, Weaver A. Prevalence of the chronic sinusitis diagnosis in Olmsted County, Minnesota. Arch Otolaryngol Head Neck Surg. 2004;130(3):320-323.

10. Chen Y, Dales R, Lin M. The epidemiology of chronic rhinosinusitis in Canadians. Laryngoscope. 2003;113(7):1199-1205.

11. Greisner WA 3rd, Settipane GA. Hereditary factor for nasal polyps. Allergy Asthma Proc. 1996;17(5):283-286.

12. Ahsan SF, Jumans S, Nunez DA. Chronic rhinosinusitis: a comparative study of disease occurrence in North of Scotland and Southern Caribbean otolaryngology outpatient clinics over a two month period. Scott Med J. 2004;49(4):130-133.

13. Hastan D, Fokkens WJ, Bachert C, et al. Chronic rhinosinusitis in Europe - an underestimated disease. A GA(2)LEN study. Allergy. 2011; 66(9):1216-1223.

14. Pilan RR, Pinna FR, Bezerra TF, et al. Prevalence of chronic rhinosinusitis in Sao Paulo. Rhinology. 2012;50(2):129-138.

15. Johansson L, Akerlund A, Holmberg K, Melen I, Bende M. Prevalence of nasal polyps in adults: the Skovde population based study. Ann Otol Rhinol Laryngol. 2003;112(7):625-629.

16. Min YG, Jung HW, Kim HS, Park SK, Yoo KY. Prevalence and risk factors of chronic sinusitis in Korea: results of a nationwide survey. Eur Arch Otorhinolaryngol. 1996;253(7):435-439.

17. Hedman J, Kaprio J, Poussa T, Nieminen MM. Prevalence of asthma, aspirin intolerance, nasal polyposis and chronic obstructive pulmonary disease in a population-based study. Int J Epidemiol. 1999;28(4): 717-722.

18. Klossek JM, Neukirch F, Pribil C, et al. Prevalence of nasal polyposis in France: a cross-sectional, case-control study. Allergy. 2005;60(2): 233-237.

19. Larsen PL, Tos M. Origin of nasal polyps. Laryngoscope. 1991;101(3): 305-312.

20. Larsen PL, Tos M. Site of origin of nasal polyps. Transcranially removed nasoethmoidal blocks as a screening method for nasal polyps in autopsy material. Rhinology. 1995;33(4):185-188.

21. Roca-Ferrer J, Garcia-Garcia FJ, Pereda J, et al. Reduced expression of COXs and production of prostaglandin $\mathrm{E}(2)$ in patients with nasal polyps with or without aspirin-intolerant asthma. J Allergy Clin Immunol. 2011;128(1):66-72.
22. Kern RC, Conley DB, Walsh W, et al. Perspectives on the etiology of chronic rhinosinusitis: an immune barrier hypothesis. Am J Rhinol. 2008;22(6):549-559.

23. Perez-Novo CA, Waeytens A, Claeys C, Cauwenberge PV, Bachert C. Staphylococcus aureus enterotoxin B regulates prostaglandin E2 synthesis, growth, and migration in nasal tissue fibroblasts. J Infect Dis. 2008;197(7):1036-1043

24. Tan BK, Li QZ, Suh L, et al. Evidence for intranasal antinuclear autoantibodies in patients with chronic rhinosinusitis with nasal polyps. J Allergy Clin Immunol. 2011;128(6):1198-1206.

25. Larson DA, Han JK. Microbiology of sinusitis: does allergy or endoscopic sinus surgery affect the microbiologic flora? Curr Opin Otolaryngol Head Neck Surg. 2011;19(3):199-203.

26. Nadel DM, Lanza DC, Kennedy DW. Endoscopically guided cultures in chronic sinusitis. Am J Rhinol. 1998;12(4):233-241.

27. Stephenson MF, Mfuna L, Dowd SE, et al. Molecular characterization of the polymicrobial flora in chronic rhinosinusitis. J Otolaryngol Head Neck Surg. 2010;39(2):182-187.

28. Ramadan HH, Sanclement JA, Thomas JG. Chronic rhinosinusitis and biofilms. Otolaryngol Head Neck Surg. 2005;132(3):414-417.

29. Psaltis AJ, Weitzel EK, Ha KR, Wormald PJ. The effect of bacterial biofilms on post-sinus surgical outcomes. Am J Rhinol. 2008;22(1):1-6.

30. Prince AA, Steiger JD, Khalid AN, et al. Prevalence of biofilmforming bacteria in chronic rhinosinusitis. Am J Rhinol. 2008;22(3): 239-245.

31. Fairbanks DN. Inflammatory diseases of the sinuses: bacteriology and antibiotics. Otolaryngol Clin North Am. 1993;26(4):549-559.

32. Ponikau JU, Sherris DA, Kern EB, et al. The diagnosis and incidence of allergic fungal sinusitis. Mayo Clin Proc. 1999;74(9):877-884.

33. Fokkens WJ, Lund VJ, Mullol J, et al. European position paper on rhinosinusitis and nasal polyps 2012. Rhinol Suppl. 2012;23:1-298.

34. Stankiewicz JA, Chow JM. A diagnostic dilemma for chronic rhinosinusitis: definition accuracy and validity. Am J Rhinol. 2002; 16(4):199-202.

35. Orlandi RR, Terrell JE. Analysis of the adult chronic rhinosinusitis working definition. Am J Rhinol. 2002;16(1):7-10.

36. Hwang PH, Irwin SB, Griest SE, Caro JE, Nesbit GM. Radiologic correlates of symptom-based diagnostic criteria for chronic rhinosinusitis. Otolaryngol Head Neck Surg. 2003;128(4):489-496.

37. Bhattacharyya N, Lee LN. Evaluating the diagnosis of chronic rhinosinusitis based on clinical guidelines and endoscopy. Otolaryngol Head Neck Surg. 2010;143(1):147-151.

38. Bhattacharyya N, Fried MP. The accuracy of computed tomography in the diagnosis of chronic rhinosinusitis. Laryngoscope. 2003;113(1): $125-129$.

39. Bhattacharyya N, Jones DT, Hill M, Shapiro NL. The diagnostic accuracy of computed tomography in pediatric chronic rhinosinusitis. Arch Otolaryngol Head Neck Surg. 2005;130(9):1029-1032.

40. Lin HW, Bhattacharyya N. Diagnostic and staging accuracy of magnetic resonance imaging for the assessment of sinonasal disease. Am J Rhinol Allergy. 2009;23(1):36-39.

41. Harvey RJ, Goddard JC, Wise SK, Schlosser RJ. Effects of endoscopic sinus surgery and delivery device on cadaver sinus irrigation. Otolaryngol Head Neck Surg. 2008;139(1):137-142.

42. Snidvongs K, Chaowanapanja P, Aeumjaturapat S, Chusakul S, Praweswararat $P$. Does nasal irrigation enter paranasal sinuses in chronic rhinosinusitis? Am J Rhinol. 2008;22(5):483-486.

43. Hyo N, Takano H, Hyo Y. Particle deposition efficiency of therapeutic aerosols in the human maxillary sinus. Rhinology. 1989;27(1): $17-26$.

44. Grobler A, Weitzel EK, Buele A, et al. Pre- and postoperative sinus penetration of nasal irrigation. Laryngoscope. 2008;118(11): 2078-2081.

45. Singhal D, Weitzel EK, Lin E, et al. Effect of head position and surgical dissection on sinus irrigant penetration in cadavers. Laryngoscope. 2010;120(12):2528-2531 
46. Harvey R, Hannan SA, Badia L, Scadding G. Nasal saline irrigations for the symptoms of chronic rhinosinusitis. Cochrane Database Syst Rev. 2007;3:CD006394.

47. Rudmik L, Hoy M, Schlosser RJ, et al. Topical therapies in the management of chronic rhinosinusitis: an evidence-based review with recommendations. Int Forum Allergy Rhinol. Epub October 8, 2012.

48. Pynnonen MA, Mukerji SS, Kim HM, Adams ME, Terrell JE. Nasal saline for chronic sinonasal symptoms: a randomized controlled trial. Arch Otolaryngol Head Neck Surg. 2007;133(11):1115-1120.

49. Liang KL, Su MC, Tseng HC, Jiang RS. Impact of pulsatile nasal irrigation on the prognosis of functional endoscopic sinus surgery. J Otolaryngol Head Neck Surg. 2008;37(2):148-153.

50. Freeman S?R, Sivayoham ES, Jepson K, de Carpentier J. A preliminary randomized controlled trial evaluating the efficacy of saline douching following endoscopic sinus surgery. Clin Otolaryngol. 2008;33(5): $462-465$.

51. Shoseyov D, Bibi H, Shai P, Shoseyov N, Shazberg G, Hurvitz H. Treatment with hypertonic saline versus normal saline nasal wash of pediatric chronic sinusitis. J Allergy Clin Immunol. 1998;101(5): 602-605.

52. Bachmann G, Hommel G, Michel O. Effect of irrigation of the nose with isotonic salt solution on adult patients with chronic paranasal sinus disease. Eur Arch Otorhinolaryngol. 2000;257(10):537-541.

53. Heatley DG, McConnell KE, Kille TL, Leverson GE. Nasal irrigation for the alleviation of sinonasal symptoms. Otolaryngol Head Neck Surg. 2001;125(1):44-48.

54. Rabago D, Zgierska A, Mundt M, Barrett B, Bobula J, Maberry R. Efficacy of daily hypertonic saline nasal irrigation among patients with sinusitis: a randomized controlled trial. J Fam Pract. 2002;51(12): 1049-1055.

55. Cordray S, Harjo JB, Miner L. Comparison of intranasal hypertonic dead sea saline spray and intranasal aqueous triamcinolone spray in seasonal allergic rhinitis. Ear Nose Throat J. 2005;84(7):426-430.

56. Pinto JM, Elwany S, Baroody FM, Nacierio RM. Effects of saline sprays on symptoms after endoscopic sinus surgery. Am J Rhinol. 2006;20(2): 191-196.

57. Hauptman G, Ryan MW. The effect of saline solutions on nasal patency and mucociliary clearance in rhinosinusitis patients. Otolaryngol Head Neck Surg. 2007;137(5):815-821.

58. Xaubet A, Mullol J, Lopez E, et al. Comparison of the role of nasal polyp and normal nasal mucosal epithelial cells on in vitro eosinophil survival. Mediation by GM-CSF and inhibition by dexamethasone. Clin Exp Allergy. 1994;24(4):307-317.

59. Mullol J, Xaubet A, Gaya A, et al. Cytokine gene expression and release from epithelial cells. A comparison study between healthy nasal mucosa and nasal polyps. Clin Exp Allergy. 1995;25(7):607-615.

60. Lildholdt T, Rundcrantz H, Lindqvist N. Efficacy of topical corticosteroid powder for nasal polyps: a double-blind, placebo-controlled study of budesonide. Clin Otolaryngol Allied Sci. 1995;20(1):26-30.

61. Adappa ND, Wei CC, Palmer JN. Nasal irrigation with or without drugs: the evidence. Curr Opin Otolaryngol Head Neck Surg. 2012;20(1): 53-57.

62. Joe SA, Thambi R, Huang J. A systematic review of the use of intranasal steroids in the treatment of chronic rhinosinusitis. Otolaryngol Head Neck Surg. 2008;139(3):340-347.

63. Rudmik L, Schlosser RJ, Smith TL, Soler ZM. Impact of topical nasal steroid therapy on symptoms of nasal polyposis: a meta-analysis. Laryngoscope. 2012;122(7):1431-1437.

64. Snidvongs K, Kalish L, Sacks R, Craig JC, Harvey RJ. Topical steroid for chronic rhinosinusitis without polyps. Cochrane Database Syst Rev. 2011;8:CD009274.

65. Snidvongs K, Kalish L, Sacks R, Sivasubramanian R, Cope D, Harvey RJ. Topical steroids for nasal polyps. Cochrane Database Syst Rev.

66. Kalish LH, Arendts G, Sacks R, Craig JC. Topical steroids in chronic rhinosinusitis without polyps: a systematic review and meta-analysis. Otolaryngol Head Neck Surg. 2009;141(6):674-683.
67. Rotenberg BW, Zhang I, Arra I, Payton KB. Postoperative care for Samter's triad patients undergoing endoscopic sinus surgery: a doubleblinded, randomized controlled trial. Laryngoscope. 2011;121(12): 2702-2705.

68. Sykes DA, Wilson R, Chan KL, Mackay IS, Cole PJ. Relative importance of antibiotic and improved clearance in topical treatment of chronic mucopurulent rhinosinusitis. A controlled study. Lancet. 1986; 2(8503):359-360.

69. Desrosiers MY, Salas-Prato M. Treatment of chronic rhinosinusitis refractory to other treatments with topical antibiotic therapy delivered by means of a large-particle nebulizer: results of a controlled trial. Otolaryngol Head Neck Surg. 2001;125(3):265-269.

70. Videler WJ, van Drunen CM, Reitsma JB, Fokkens WJ. Nebulized bacitracin/colimycin: a treatment option in recalcitrant chronic rhinosinusitis with Staphylococcus aureus? A double-blind, randomized, placebo-controlled, cross-over pilot study. Rhinology. 2008;46(2):92-98.

71. Jervis-Bardy J, Boase S, Psaltis A, Foreman A, Wormald PJ. A randomized trial of mupirocin sinonasal rinses versus saline in surgically recalcitrant staphylococcal chronic rhinosinusitis. Laryngoscope. 2012;122(10):2148-2153.

72. Lim M, Citardi MJ, Leong JL. Topical antimicrobials in the management of chronic rhinosinusitis: a systematic review. Am J Rhinol. 2008;22(4):381-389.

73. Ha KR, Psaltis AJ, Butcher AR, Wormald PJ, Tan LW. In vitro activity of mupirocin on clinical isolates of Staphylococcus aureus and its potential implications in chronic rhinosinusitis. Laryngoscope. 2008;118(3): 535-540.

74. Le T, Psaltis A, Tan LW, Wormald PJ. The efficacy of topical antibiofilm agents in a sheep model of rhinosinusitis. Am Journal Rhinol. 2008; 22(6):560-567.

75. Chiu AG, Palmer JN, Woodworth BA, et al. Baby shampoo nasal irrigations for the symptomatic post-functional endoscopic sinus surgery patient. Am J Rhinol. 2008;22(1):34-37.

76. Lynch H, Milgrom P. Xylitol and dental caries: an overview for clinicians. J Calif Dent Assoc. 2003;31(3):205-209.

77. Weissman JD, Fernandez F, Hwang PH. Xylitol nasal irrigation in the management of chronic rhinosinusitis: a pilot study. Laryngoscope. 2011;121(11):2468-2472.

78. Raza T, ElsherifHS, Zulianello L, Plouin-Gaudon I, Landis BN, Lacroix JS. Nasal lavage with sodium hypochlorite solution in Staphylococcus aureus persistent rhinosinusitis. Rhinology. 2008;46(1):15-22.

79. Poetker DM, Jakubowski LA, Lal D, Hwang PH, Wright ED, Smith TL. Oral corticosteroids in the management of adult chronic rhinosinusitis with and without nasal polyps: an evidence-based review with recommendations. Int Forum Allergy Rhinol. Epub August 7, 2012.

80. Hissaria P, Smith W, Wormald PJ, et al. Short course of systemic corticosteroids in sinonasal polyposis: a double-blind, randomized, placebo-controlled trial with evaluation of outcome measures. J Allergy Clin Immunol. 2006;118(1):128-133.

81. Kroflic B, Coer A, Baudoin T, Kalogjera L. Topical furosemide versus oral steroid in preoperative management of nasal polyposis. Eur Arch Otorhinolaryngol. 2006;263(8):767-771.

82. Van Zele T, Gevaert P, Holtappels G, et al. Oral steroids and doxycycline: two different approaches to treat nasal polyps. J Allergy Clin Immunol. 2010;125(5):1069-1076.

83. Kirtsreesakul V, Wongsritrang K, Ruttanaphol S. Clinical efficacy of a short course of systemic steroids in nasal polyposis. Rhinology. 2011;49(5):525-532.

84. Vaidyanathan S, Barnes M, Williamson P, Hopkinson P, Donnan PT, Lipworth B. Treatment of chronic rhinosinusitis with nasal polyposis with oral steroids followed by topical steroids: a randomized trial. Ann Intern Med. 2011;154(5):293-302.

85. Wright ED, Agrawal S. Impact of perioperative systemic steroids on surgical outcomes in patients with chronic rhinosinusitis with polyposis: evaluation with the novel Perioperative Sinus Endoscopy (POSE) scoring system. Laryngoscope. 2007;117(11 Pt 2, Suppl 115): $1-28$. 
86. Lal D, Hwang PH. Oral corticosteroid therapy in chronic rhinosinusitis without polyposis: a systematic review. Int Forum Allergy Rhinol. 2011;1(2):136-143.

87. Subramanian HN, Schechtman KB, Hamilos DL. A retrospective analysis of treatment outcomes and time to relapse after intensive medical treatment for chronic sinusitis. Am J Rhinol. 2002;16(6):303-312.

88. Lal D, Scianna JM, Stankiewicz JA. Efficacy of targeted medical therapy in chronic rhinosinusitis, and predictors of failure. Am J Rhinol Allergy. 2009;23(4):396-400.

89. Tosca MA, Cosentino C, Pallestrini E, et al. Medical treatment reverses cytokine pattern in allergic and nonallergic chronic rhinosinusitis in asthmatic children. Pediatr Allergy Immunol. 2003;14(3):238-241.

90. Rupa V, Jacob M, Mathews MS, Seshadri MS. A prospective, randomized, placebo-controlled trial of postoperative oral steroid in allergic fungal sinusitis. Eur Arch Otorhinolaryngol. 2010;267(2):233-238.

91. Ikram M,Abbas A, Suhail A, Onali MA, Akhtar S, Iqbal M. Management of allergic fungal sinusitis with postoperative oral and nasal steroids: a controlled study. Ear Nose Throat J. 2009;88(4):E8-E11.

92. Landsberg R, Segev Y, DeRowe A, Landau T, Khafif A, Fliss DM. Systemic corticosteroids for allergic fungal rhinosinusitis and chronic rhinosinusitis with nasal polyposis: a comparative study. Otolaryngol Head Neck Surg. 2007;136(2):252-257.

93. Poetker DM, Reh DD. A comprehensive review of the adverse effects of systemic corticosteroids. Otolaryngol Clin North Am. 2010;43(4) 753-768.

94. Legent F, Bordure P, Beauvillain C, Berche P. A double-blind comparison of ciprofloxacin and amoxycillin/clavulanic acid in the treatment of chronic sinusitis. Chemotherapy. 1994;40 Suppl 1:8-15.

95. Namyslowski G, Misiolek M, Czecior E, et al. Comparison of the efficacy and tolerability of amoxycillin/clavulanic acid $875 \mathrm{mg}$ bid with cefuroxime $500 \mathrm{mg}$ bid in the treatment of chronic and acute exacerbation of chronic sinusitis in adults. J Chemother. 2002;14(5): $508-517$.

96. Anon JB, Jacobs MR, Poole MD, et al. Antimicrobial treatment guidelines for acute bacterial rhinosinusitis. Otolaryngol Head Neck Surg. 2004;130(Suppl 1):1-45.

97. Genoway KA, Philpott CM, Javer AR. Pathogen yield and antimicrobial resistance patterns of chronic rhinosinusitis patients presenting to a tertiary rhinology centre. J Otolaryngol Head Neck Surg. 2011;40(3): 232-237.

98. Bhattacharyya N, Kepnes LJ. Assessment of trends in antimicrobial resistance in chronic rhinosinusitis. Ann Otol Rhinol Laryngol. 2008; 117(6):448-452.

99. Kingdom TT, Swain RE Jr. The microbiology and antimicrobial resistance patterns in chronic rhinosinusitis. Am J Otolaryngol. 2004;25(5): 323-328.

100. Nagai H, Shishido H, Yoneda R, Yamaguchi E, Tamura A, Kurashima A. Long-term low-dose administration of erythromycin to patients with diffuse panbronchiolitis. Respiration. 1991;58(3-4):145-149.

101. Wallwork B, Coman W, Mackay-Sim A, Greiff L, Cervin A. A double-blind, randomized, placebo-controlled trial of macrolide in the treatment of chronic rhinosinusitis. Laryngoscope. 2006;116(2): 189-193.

102. Videler WJ, Badia L, Harvey RJ, et al. Lack of efficacy of long-term, low-dose azithromycin in chronic rhinosinusitis: a randomized controlled trial. Allergy. 2011;66(11):1457-1468.

103. Haruna S, Shimada C, Ozawa M, Fukami S, Moriyama H. A study of poor responders for long-term, low-dose macrolide administration for chronic sinusitis. Rhinology. 2009;47(1):66-71.

104. Suzuki H, Ikeda K, Honma R, et al. Prognostic factors of chronic rhinosinusitis under long-term low-dose macrolide therapy. ORL $J$ Otorhinolaryngol Relat Spec. 2000;62(3):121-127.

105. Malhotra-Kumar S, Lammens C, Coenen S, Van Herck K, Goossens H. Effect of azithromycin and clarithromycin therapy on pharyngeal carriage of macrolide-resistant streptococci in healthy volunteers: a randomized, double-blind, placebo-controlled study. Lancet. 2007; 369(9560):482-490.
106. Ponikau JU, Sherris DA, Weaver A, Kita H. Treatment of chronic rhinosinusitis with intranasal amphotericin B: a randomized, placebocontrolled, double-blind pilot trial. J Allergy Clin Immunol. 2005; 115(1):125-131.

107. Liang KL, Su MC, Shiao JY, et al. Amphotericin B irrigation for the treatment of chronic rhinosinusitis without nasal polyps: a randomized, placebo-controlled, double-blind study. Am J Rhinol. 2008;22(1): $52-58$.

108. Ebbens FA, Scadding GK, Badia L, et al. Amphotericin B nasal lavages: not a solution for patients with chronic rhinosinusitis. J Allergy Clin Immunol. 2006;118(5):1149-1156.

109. Ebbens FA, Georgalas C, Luiten S, et al. The effect of topical amphotericin $\mathrm{B}$ on inflammatory markers in patients with chronic rhinosinusitis: a multicenter randomized controlled study. Laryngoscope. 2009; 119(2):401-408.

110. Sacks PL 4th, Harvey RJ, Rimmer J, Gallagher RM, Sacks R. Antifungal therapy in the treatment of chronic rhinosinusitis: a meta-analysis. Am J Rhinol Allergy. 2012;26(2):141-147.

111. Parnes SM, Chuma AV. Acute effects of antileukotrienes on sinonasal polyposis and sinusitis. Ear Nose Throat J. 2000;79(1):18-20, 24-25.

112. Nonaka M, Sakanushi A, Kusama K, Ogihara N, Yagi T. One-year evaluation of combined treatment with an intranasal corticosteroid and montelukast for chronic rhinosinusitis associated with asthma. J Nippon Med Sch. 2010;77(1):21-28.

113. Mostafa BE, Abdel Hay H, Mohammed HE, Yamani M. Role of leukotriene inhibitors in the postoperative management of nasal polyps. ORL J Otorhinolaryngol Relat Spec. 2005;67(3):148-153.

114. Stewart RA, Ram B, Hamilton G, Weiner J, Kane KJ. Monteleukast as an adjunct to oral and inhaled steroid therapy in chronic nasal polyposis. Otolaryngol Head Neck Surg. 2008;139(5):682-687.

115. Wise SK, Ahn CN, Schlosser RJ. Localized immunoglobulin E expression in allergic rhinitis and nasal polyposis. Curr Opin Otolaryngol Head Neck Surg. 2009;17(3):216-222.

116. Pinto JM, Mehta N, DiTineo M, Wang J, Baroody FM, Naclerio RM. A randomized, double-blind, placebo-controlled trial of anti-IgE for chronic rhinosinusitis. Rhinology. 2010;48(3):318-324.

117. Gevaert P, Van Bruaene N, Cattaert T, et al. Mepolizumab, a humanized anti-IL-5 mAb, as a treatment option for severe nasal polyposis. J Allergy Clin Immunol. 2011;128(5):989-995.

118. Gevaert P, Lang-Loidolt D, Lackner A, et al. Nasal IL-5 levels determine the response to anti-IL-5 treatment in patients with nasal polyps. J Allergy Clin Immunol. 2006;118(5):1133-1141.

119. Forer B, Kivity S, Sade J, Landsberg R. Aspirin desensitization for ASA triad patients - prospective study of the rhinologist's perspective. Rhinology. 2011;49(1):95-99.

120. Stevenson DD, Pleskow WW, Simon RA, et al. Aspirin-sensitive rhinosinusitis asthma: a double-blind crossover study of treatment with aspirin. J Allergy Clin Immunol. 1984;73(4):500-507.

121. Rozsasi A, Polzehl D, Deutschle T, et al. Long-term treatment with aspirin desensitization: a prospective clinical trial comparing 100 and $300 \mathrm{mg}$ aspirin daily. Allergy. 2008;63(9):1228-1234.

122. Smith TL, Batra PS, Seiden AM, Hannley M. Evidence supporting endoscopic sinus surgery in the management of adult chronic rhinosinusitis: a systematic review. Am J Rhinol. 2005;19(6):537-543.

123. Hopkins C, Browne JP, Slack R, et al. The national comparative audit of surgery for nasal polyposis and chronic rhinosinusitis. Clin Otolaryngol. 2006;31(5):390-398.

124. Chester AC, Antisdel JL, Sindwani R. Symptom-specific outcomes of endoscopic sinus surgery: a systematic review. Otolaryngol Head Neck Surg. 2009;140(5):633-639.

125. Bhandarkar ND, Mace JC, Smith TL. Endoscopic sinus surgery reduces antibiotic utilization in rhinosinusitis. Int Forum Allergy Rhinol. 2011; 1(1):18-22

126. Smith TL, Kern RC, Palmer JN, et al. Medical therapy vs surgery for chronic rhinosinusitis: a prospective, multi-institutional study. Int Forum Allergy Rhinol. 2011;1(4):235-241. 
Infection and Drug Resistance

Dovepress

\section{Publish your work in this journal}

Infection and Drug Resistance is an international, peer-reviewed openaccess journal that focuses on the optimal treatment of infection (bacterial, fungal and viral) and the development and institution of preventive strategies to minimize the development and spread of resistance. The journal is specifically concerned with the epidemiology of antibiotic

resistance and the mechanisms of resistance development and diffusion in both hospitals and the community. The manuscript management system is completely online and includes a very quick and fair peerreview system, which is all easy to use. Visit http://www.dovepress.com/ testimonials.php to read real quotes from published authors.

Submit your manuscript here: http://www.dovepress.com/infection-and-drug-resistance-journal 